Krzysztof Opaliński

DOI: 10.33896/PorJ.2020.8.2

(e-mail: krzysztof.opalinski@ibl.waw.pl)

ORCID: 0000-0001-8775-4953

Patrycja Potoniec

(e-mail: patrycja.potoniec@ibl.waw.pl)

ORCID: 0000-0002-5911-5422

(Instytut Badań Literackich Polskiej Akademii Nauk, Warszawa)

\title{
KORPUS POLSZCZYZNY XVI WIEKU
}

\section{ZALOŻENIA}

Pierwotna przyczyna podjęcia prac nad korpusem szesnastowiecznej polszczyzny są problemy, przed którymi stanął na poczatku XXI wieku zespół Pracowni Słownika Polszczyzny XVI wieku IBL PAN. Baza materiałowa tego słownika, przygotowana w połowie XX wieku ( $z$ wykorzystaniem dostępnych wówczas środków) na nośnikach o małej trwałości, po 50 latach użytkowania wykazywała znaczne ślady zniszczenia.

Baza ta składa się $z$ kopii powielaczowych transliteracji tekstów szesnastowiecznych, stanowiących podstawę źródłową Słownika polszczyzny XVI wieku (dalej: SPXVI), oraz ze słynnej (uznawanej za najliczniejsza w dziejach polskiej leksykografii [por. np. Piotrowski 2001, 102]) kartoteki kartkowej liczaccej 8 milionów fiszek. Dziś ogrom pracy włożonej w jej przygotowanie, wykonywanej w zasadzie ręcznie ( $\mathrm{z}$ użyciem maszyny do pisania i powielacza), wydaje się nie do wyobrażenia. ${ }^{1}$ Dzięki niej każdy $z$ tekstów wybranych jako źródło dla haseł SPXVI otrzymał swój odpowiednik w postaci transliterowanych matryc tekstowych.

Oprawione egzemplarze tych transliteracji (zwane egzemplarzami archiwalnymi) przez pół wieku stale były używane w Pracowni Słownika Polszczyzny XVI wieku, w obliczu jednak postępującej degradacji niezbędne było opracowanie planu ich ocalenia przed całkowitą destrukcją.

Najoczywistszym rozwiąaniem wydawało się jakiekolwiek utrwalenie materiałów w postaci cyfrowej. Dzięki możliwościom, które daje komputerowe przetwarzanie i zapisywanie danych, droga rozwoju badań językoznawczych (zwłaszcza na dużych zasobach danych) jest od dawna wytyczona: „nowoczesne nośniki informacji stwarzaja (...) szeroki dostęp (także przez sieci komputerowe) i do wielkich zbiorów tekstów (zwanych

1 Wystarczy powiedzieć, że miesięczna norma pracy - przepisanie, skontrolowanie (trzykrotne!), opatrzenie hasłami i uporzadkowanie alfabetyczne fiszek - dla zespołu pięcioosobowego wynosiła 10000 fiszek [SPXVI, zeszyt próbny, s. VII]. 
korpusami), które można stosunkowo swobodnie przeszukiwać" - pisał Zygmunt Saloni w 1996 roku [s. 15]. ${ }^{2}$

Mając na uwadze unikatowość bazy źródłowej SPXVI (zbiór ponad 250 tekstów transliterowanych według jednolitych zasad), celowe wydawało się nie tylko stworzenie kopii cyfrowych (np. skanów) istniejących materiałów, ale i takie ich opracowanie, by mogły być przydatne nie tylko leksykografom przygotowującym SPXVI.

\section{Ilustracja 1. Strona $z$ egzemplarza archiwalnego (transliterowanej matrycy tekstowej).}

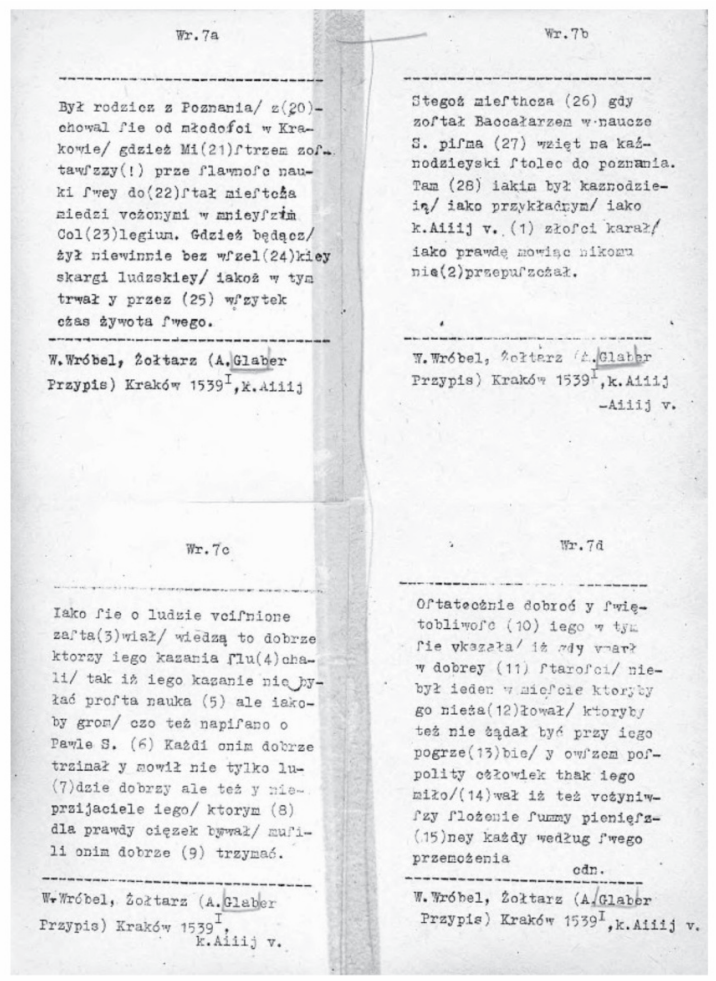

Pojawienie się na początku lat dwutysięcznych radykalnych „postulatów, dotyczących naukowego słownika przyszłości” [Żmigrodzki 2005, 9], jak zgłoszony w 2005 roku przez Piotra Żmigrodzkiego: „słowniki dokumentacyjne mogłyby bez większych strat dla nauki zostać zastapione

2 Szczegółowy opis metod gromadzenia danych językowych (tworzenia korpusu tekstów dla słowników) za pomoca komputerów przedstawił na przykładzie Collin Birmingham University International Language Database (COBUILD) T. Piotrowski w 1993 roku [s. 210-218; o historii tego projektu zob. też: https:// www.collinsdictionary.com/cobuild/]. 
elektronicznymi korpusami tekstów" [s. 9], wskazywało, że korpus tekstów szesnastowiecznych, i to korpus dostępny online, jest niezbędny i przez użytkowników pożądany [zob. uwagi w: Żmigrodzki 2005, 7-8], niezależnie od tego, czy uznać można słuszność postulatu zastąienia korpusem tak zaawansowanego przedsięwzięcia leksykograficznego jak SPXVI. ${ }^{3}$

Trzeba jednak brać pod uwagę, że „należyte opracowanie korpusu wymaga dużej pracy, wyspecjalizowanego sprzętu komputerowego i oprogramowania oraz znacznych nakładów finansowych" [Saloni 1996, 15]. Dla Pracowni Słownika Polszczyzny XVI wieku IBL PAN podjęcie się realizacji takiego zadania oznaczałoby zawieszenie prac nad SPXVI, a było to (i jest) wykluczone, ponieważ jedyna właściwa droga dla tak daleko posuniętych i tak długo trwajacych prac jak opracowanie SPXVI jest ich jak najszybsze zakończenie.

Dopiero więc uruchomiony w lutym roku 2011 Narodowy Program Rozwoju Humanistyki [https://www.gov.pl/web/nauka/narodowy-program-rozwoju-humanistyki, dostepp: 20 lutego 2020 r.] dawał szansę zdobycia odpowiednich środków finansowych na realizację takiego przedsięwzięcia i zatrudnienie osób spoza pracowni. 16 maja 2011 roku do Ministerstwa Nauki i Szkolnictwa Wyższego został więc złożony wniosek pt. Korpus Polszczyzny XVI wieku. Etap I: Dygitalizacja źródeł oraz stworzenie narzędzi informatycznych $i$ udostepnienie materiałów testowych korpusu, którego realizację przewidziano na maksymalny możliwy dla projektów finansowanych przez NPRH okres 60 miesięcy. Przy objętości materiałów, które miano poddać dygitalizacji i anotacji, oczywiste było już w momencie składania wniosku, że niemożliwe będzie przygotowanie w ciagu 5 lat w pełni funkcjonalnego korpusu językowego. Tym bardziej, że duża część prac miała być wykonana siłami ludzkimi, a nie za pomoca narzędzi automatycznych. Na etapie tworzenia wniosku wydawało się to najlepsza droga do zadowalajacego ograniczenia liczby błędów w powstającym zasobie. Przemawiał za tym stan zachowania materiałów - część kopii powielaczowych jest tak uszkodzona, że ich skanowanie byłoby zbyt skomplikowane, a inne tak nieczytelne, że stanowiłyby dla programu do automatycznego rozpoznawania tekstu (w roku 2011) wyzwanie zbyt duże. Planowane zaś wstępne (tylko dla niektórych tekstów) anotowanie znacznikami formy podstawowej i form morfosyntaktycznych (wprowadzenie takiej anotacji uznaliśmy za niezbędne minimum, by można było mówić o korpusie, ${ }^{4}$ a nie jedynie o bazie tekstów) mu-

3 Nawet w roku 2005, gdy ukazał się w „Poradniku Językowym” artykuł zawierający postulat P. Żmigrodzkiego, prace nad SPXVI były doprowadzone niemalże do końca haseł na literę $P$, tom 33. kończący publikację haseł na tę literę jest datowany na rok 2009. Obecnie, w roku 2020, trwa redakcja haseł z zakresu srożyć się - święty.

4 To dość oczywiste założenie, powtarzane często przy definiowaniu korpusu - por. np. Szałkiewicz 2013, 133. 
siało być przeprowadzane ręcznie ze względu na znaczna wariantywność graficzna i morfologiczna szesnastowiecznej polszczyzny [por. Opaliński 2007, 113], co powodowało, że niemożliwe byłoby zastosowanie do niej narzędzi automatycznych używanych do polszczyzny współczesnej.

Warto podkreślić, że w roku 2011 nie istniał w zasadzie żaden diachroniczny korpus polszczyzny, na którym moglibyśmy się wzorować. Jak w roku 2019 wskazali autorzy artykułu poświęconego zintegrowanemu korpusowi diachronicznemu,

pierwszy korpus dawnych tekstów polskich, spełniajacy standardy obowiazujące dziś przy tworzeniu takich zasobów, powstał na potrzeby dużego międzynarodowego projektu IMPACT [Król i in. 2019, 94]

i został udostępniony w styczniu 2012 [zob. Bień 2014, 76]. Korpus polszczyzny XVI wieku był pomyślany w gruncie rzeczy jako dodatek do SPXVI. Biorąc pod uwagę postulaty językoznawców, miał udostępniać materiały, którymi dysponowała Pracownia, a jednocześnie służyć leksykografom przygotowującym SPXVI. To zdeterminowało decyzje merytoryczne, które zostały podjęte przy opracowaniu założeń projektu. Jego celem, wskazanym we wniosku było:

Ocalenie, renowacja, poprawa i udostępnienie bazy transliterowanych tekstów szesnastowiecznych wykorzystywanych do tworzenia Słownika polszczyzny XVI wieku,

a spodziewany wynik stanowić miało:

- powstanie komputerowej bazy transliterowanych tekstów szesnastowiecznych o objętości około 28000 stron standardowego maszynopisu udostępnionej na witrynie internetowej Pracowni do ogólnego użytku,

- ocalenie bazy materiałowej Stownika polszczyzny XVI wieku, co zapewni jego ukończenie,

- utworzenie zasobu, który zostanie przetworzony w korpus polszczyzny XVI wieku,

- przygotowanie „małego korpusu” pozwalającego na przetestowanie możliwości planowanego w przyszłości korpusu pełnego („mały korpus” zostanie udostępniony na witrynie internetowej Pracowni w celu zbadania potrzeb użytkowników). ${ }^{5}$

Dzięki skoncentrowaniu planowanego korpusu wokół SPXVI do prac nad realizacja projektu mogliśmy przystapić $z$ :

- wyłonioną bazą źródłowa,

- jednolita baza materiałowa (teksty transliterowane),

- ustalonym zestawem wyróżnianych klas gramatycznych i odpowiednich dla nich form gramatycznych,

- przeprowadzonym hasłowaniem.

5 Cel i opis wyników to dosłowne (łącznie $z$ wyróżnieniami) cytaty $z$ „opisu projektu", będącego częścią wniosku o finansowanie złożonego w MNiSW 16 maja 2011 roku. 


\subsection{Baza źródłowa}

Baza źródłowa została opisana we wstępie do pierwszego tomu SPXVI. ${ }^{6}$ Teksty do niej dobrano zgodnie $z$ następujacymi założeniami (nieodbiegajacymi od formułowanych w odniesieniu do współczesnych korpusów językowych [por. np. Górski, Łaziński 2012]:

Materiał staraliśmy się wybrać tak, by znalazła się w nim reprezentacja możliwie wszystkich form piśmienniczych (...). Chcieliśmy także w naszym materiale widzieć wypowiedzi o możliwie różnym stopniu literackości i możliwie różnej genezie społecznej (...). Nie chcieliśmy zaniedbać możliwie pełnej reprezentacji wszystkich dzielnic Polski. Chcieliśmy też w miarę możności dobrać materiał tak, by reprezentował pełny chronologiczny rozwój w obrębie opracowywanego stulecia [Mayenowa 1966, VIII; wyróżnienia PP].

Założenia te obwarowano od razu pewnymi zastrzeżeniami, powtarzalnymi w odniesieniu do słowników historycznej polszczyzny [por. np. Adamiec 2015, 13]:

- „ułamkowość materiału jest losem każdego historycznego słownika”,

- „jednostronność Słownika naszego wynika stąd, że jego podstawowym materiałem sa druki",

- „materiał rękopiśmienny został wprowadzony głównie jako swoiste tło dla języka druków" [Mayenowa 1966, IX].

I ostatecznym wnioskiem: „Słownik zatem jest przede wszystkim thesaurusem języka literackiego w najrozmaitszych jego odmianach" [Mayenowa 1966, IX], który znajduje swoje rozwinięcie w uwadze poniekąd usprawiedliwiającej zawężenie materiału słownikowego:

nie jest także pozbawione argumentacji stanowisko, które właśnie wybitnym indywidualnościom przypisuje odzwierciedlanie głównego toru rozwojowych tendencji języka [Mayenowa 1966, IX].

Baza źródłowa opiera się głównie na pierwszych wydaniach szesnastowiecznych utworów piśmienniczych (nieliczne teksty ekscerpowano $z$ wydań późniejszych, na ogół w wypadku, gdy dostęp do pierwodruków był niemożliwy lub bardzo utrudniony) oraz niewielu rękopisach. Większe objętościowo teksty zostały włączone tylko częściowo, zgodnie z założeniem, że część taka przy dużej objętości tekstu jest w pełni reprezentatywna:

6 Składajace się na nia teksty (tzw. kanon podstawowy) wykazywane sa w każdym tomie SPXVI w Skorowidzu tekstów źródłowych I. 


\begin{tabular}{|c|c|}
\hline objętość tekstu w literach & procent ekscerpcji \\
\hline powyżej 300 000 & 20 \\
\hline 150 000-300 000 & 50 \\
\hline poniżej 150 000 & 100 \\
\hline
\end{tabular}

Założenie to zostało poddane weryfikacji, porównanie zasobu słownictwa w tekście literackim - Psalterzu Dawidowym Kochanowskiego [z 1579 roku] i w przekładzie psałterza wchodzącym w skład Biblii Leopolity [z 1561 roku], wykazało znaczna przewage tego pierwszego. To oraz zewnętrzne przyczyny (powiąanie SPXVI z serią wydawnicza Biblioteka Pisarzów Polskich) wpłynęło na decyzję o modyfikacji wypracowanych założeń statystycznych i włączeniu wielu tekstów literackich w 100\%, niezależnie od ich objętości.

Szczegółowa analizę zasobu słownictwa w różnych tekstach kanonu źródłowego SPXVI przedstawił w swojej części wstępu do tomu 1. Władysław Kuraszkiewicz [1966, XIV-XXV].

\subsection{Baza materiałowa}

Szczególną wartość tej bazy określa fakt, że transliteracja tekstów szesnastowiecznych została w większości wykonana na potrzeby SPXVI, ${ }^{7}$ a teksty te opracowano zgodnie z Zasadami wydawania tekstów staropolskich. Projekt. ${ }^{8}$ Jednolitość tego zasobu stanowi o jego wyjątkowości, szczególnie gdy weźmie się pod uwagę znaczne zróżnicowanie tekstów drukowanych w XVI wieku, zarówno pod względem graficznym, jak i ortograficznym.

Opracowane według tych zasad teksty transliterowane powielono wielokrotnie, tak by dysponować odpowiednią liczba kopii całości (egzemplarzy archiwalnych) oraz by każda jednostka danego tekstu otrzymała zawierająca ja fiszkę wraz $z$ kilkuzdaniowym kontekstem. ${ }^{9}$ Udostępnienie

$7 \mathrm{Z}$ nielicznymi wyjatkami, gdy wykorzystano materiały już istniejace lub powstajace niemalże jednocześnie $z$ kartoteka SPXVI, jak np. Zapiski i roty polskie $X V-X V I$ wieku $z$ ksiag sadowych ziemi warszawskiej wydane w 1950 r.

8 Zresztą w opracowaniu tegoż (dziś już nieco przestarzałego i poddawanego licznym modyfikacjom przez redakcje i edytorów, choć nadal obowiązującego) zbioru zasad przetwarzania tekstu dawnego (transkrypcji i transliteracji o różnych poziomach szczegółowości) brali udział członkowie redakcji SPXVI i współpracownicy zespołu leksykograficznego, a przede wszystkim: M.R. Mayenowa, F. Pepłowski i J. Woronczak oraz W. Kuraszkiewicz i W. Taszycki [por. Hrabec 1966, V-VI].

9 Zajęło to zresztą wiele lat (gdy ukazywał się zeszyt próbny SPXVI, w 7 lat od powstania Pracowni, przygotowanie materiałów nie było jeszcze zakończone), podczas których opracowano też zasady redakcyjne SPXVI. Por. też opis tradycyjnych metod ekscerpcji [Żmigrodzki 2009, 30-31]. 
takiej bazy jako zasobu internetowego umożliwiłoby badaczom dawnej polszczyzny korzystanie $z$ najobszerniejszego zbioru tekstów renesansowych transliterowanych według jednolitych zasad.

\subsection{Zestaw klas i form gramatycznych}

W hasłach SPXVI obowiąuje tzw. tradycyjny podział na części mowy i przysługujące im formy gramatyczne. Zważywszy na okres, w którym powstawały założenia metodologiczne SPXVI jest to oczywiste. Podział ten został przez Krystynę Wilczewską scharakteryzowany ogólnie we wstępie do tomu 1. SPXVI [Wilczewska 1966, XXVI-XLII], a bardziej szczegółowo w Instrukcji redakcyjnej „Stownika” [patrz: http://spxvi.edu.pl/instrukcja, rozdz. IV i V]. Równie oczywiste w połowie XX wieku wydawało się przyjęcie $\mathrm{w}$ słowniku naukowym ${ }^{10}$ konwencji opisu gramatycznego za pomoca skrótów nazw łacińskich. Kierując się wymogami, jakie narzuca redagowanie haseł SPXVI, zakładaliśmy używanie obowiąujących w nim konwencji klasyfikacji i opisu gramatycznego również w planowanym korpusie.

\subsection{Hasłowanie}

Kartoteka fiszkowa w Pracowni Słownika Polszczyzny XVI wieku jest w zasadzie uporzadkowana. Po zebraniu i transliteracji źródeł przeprowadzono hasłowanie i wszystkie wyekscerpowane na potrzeby SPXVI jednostkowe reprezentacje tekstowe danego leksemu zakwalifikowano do formy podstawowej, a zawierajace je fiszki umieszczono w odpowiednim dla danego hasła zbiorze materiałów.

Między innymi dzięki temu mógł powstać indeks zbiorczy wszystkich haseł SPXVI wraz z orientacyjną liczbą użyć tekstowych dla każdego $z$ nich. ${ }^{11}$

W klasyfikacji materiałów zdarzają się, oczywiście, błędy, ${ }^{12}$ wariantywność morfologiczna i ortograficzna dawnej polszczyzny nastrę-

10 Na uznanie SPXVI za słownik naukowy wskazuja już zawarte we wstępie do niego uwagi mówiące o nim jako o „podstawie materiałowej” dla językoznawstwa i stylistyki historycznej oraz historii literatury [Mayenowa 1966, VIII]. Spełnia on także wszystkie kryteria przypisywane słownikowi naukowemu przez P. Żmigrodzkiego [2005, 5].

11 Indeks ten jest wciąz uzupełniany o hasła nowe, wyekscerpowane ze źródeł spoza podstawowego kanonu tekstów - jego aktualna wersja znajduje się na portalu internetowym SPXVI pod adresem: http://spxvi.edu.pl/indeks /

12 Zwodnicze bywaja, jak wiadomo, formy lub leksemy homonimiczne czy homografy - np. w materiale hasła STRONA do tej pory znajduja się zarówno fiszki o znaczeniu 'część instrumentu', jak i należące do znaczeń zwiąanych z opisami stosunków przestrzennych, choć w indeksie wyróżnione sa hasła 1.STRONA i 2 STRONA (jednak ich liczebność nie odpowiada stanowi faktycznemu). 
cza trudności nawet doświadczonym badaczom [por. np. Gruszczyński 2010, 28-30]. Błędy te korygowane są na ogól w momencie opracowywania kolejnych haseł, więc w części materiałów (rozpoczynających się na litery $S-\dot{Z}$ ) korekty takiej jeszcze nie przeprowadzono. Nawet jednak niedoskonała siatka haseł może stanowić dobry punkt odniesienia dla planowanego korpusu tekstów szesnastowiecznych - zbiór leksemów, do których przyporządkowane muszą być wszystkie jednostki tekstu w całym zasobie. Ograniczenie zbioru możliwych form podstawowych to pomoc dla osób zajmujących się przypisywaniem odpowiednich znaczników jednostkom tekstu w korpusie oraz sposób na uniknięcie tworzenia przez wykonawców form nieistniejących. ${ }^{13}$

Ilustracja 2. Kartoteka fiszkowa Słownika polszczyzny XVI wieku.

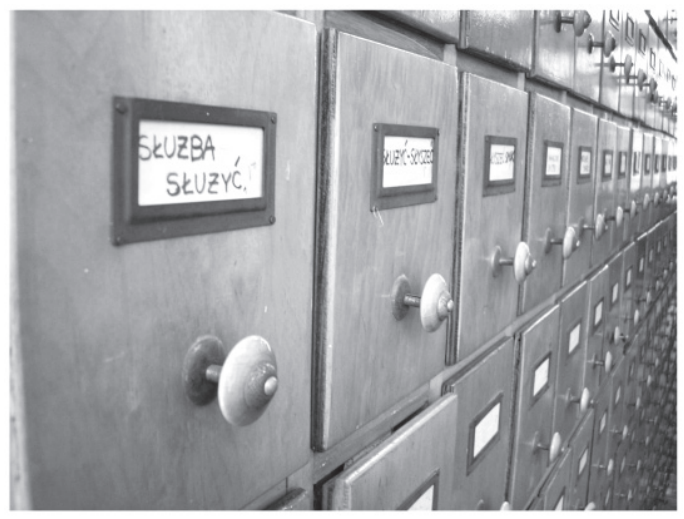

\section{REALIZACJA}

Przy opracowaniu koncepcji korpusu tekstów XVI-wiecznych założenia przyjęte kilka dekad temu dla materiału SPXVI należało zweryfikować na podstawie doświadczeń w pracach redakcyjnych oraz dostosować je do możliwości nowych technologii. $Z$ racji ogromu przedsięwzięcia prace należało podzielić na kilka etapów, $z$ których pierwszy miał polegać na uzyskaniu spójnej elektronicznej bazy tekstów.

13 Prawdopodobne jest, że np. nieistniejaca dziś forma pierwszej osoby liczby mnogiej czasu teraźniejszego porzem większości anotatorów nie skojarzyłaby się $z$ forma podstawowa PROĆ (dziś: PRUĆ) [zob. SPXVI, t. 30, s. 325], a raczej sprowokowałaby wytworzenie *PORAĆ. 


\subsection{Baza tekstów}

Początkowo rozważano pozyskanie tekstów w sposób możliwie zautomatyzowany. Wykonano w tym celu próby skanowania egzemplarzy archiwalnych i cyfrowego rozpoznawania tekstu. Niestety efekt tych prób nie był zadowalajacy, głównie ze względu na licznie występujące na kopiach powielaczowych i rozmywające tekst plamy tuszu czy niedotłoczone i nieodbite znaki oraz skazy słabej jakości papieru. ${ }^{14}$

\section{Ilustracja 3. Fragment matrycy tekstowej egzemplarza archiwalnego.}

$$
\begin{aligned}
& \text { (5)A i.plie bi Ine nú czu nal }
\end{aligned}
$$

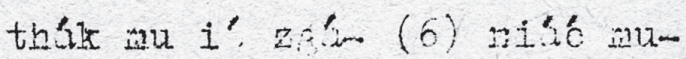

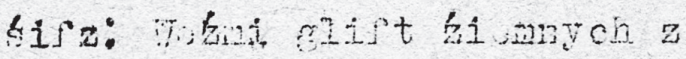

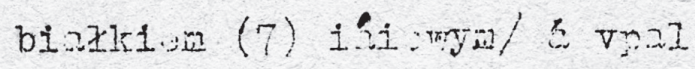

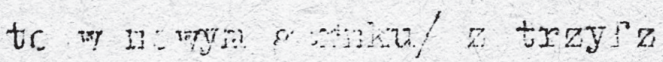

Dodatkowa trudnościa była organizacja tekstu na stronach egzemplarzy archiwalnych, która polega na podziale tekstu na tzw. ćwiartki, odpowiadające wielkością fiszce w formacie A6, oraz tekstem dodatkowym umieszczonym na każdej ćwiartce, zawierającym informacje o lokalizacji w tekście źródłowym i numerze ćwiartki (zob. ilustracja 1.). Nadto niektóre teksty na ćwiartkach miały dopisywane nierzadko uwspółcześnione i skrócone rozszerzenia kontekstu $z$ poprzednich ćwiartek, by łatwiej było zrozumieć dany fragment. Dopiski te oraz informacje lokalizacyjne po cyfrowym rozpoznaniu tekstu należałoby usunać, a to niepotrzebnie wydłużyłoby pracę nad tekstem. Przeciwko przetwarzaniu kopii powielaczowych przemawiały również błędy w przepisaniu niektórych tekstów. ${ }^{15}$ Błędy te skrupulatnie i wielokrotnie poprawiane w pracach redakcyjnych i tak implikowałyby konieczność przeprowadzenia korekt, które trudno byłoby zautomatyzować.

W rezultacie czynności przygotowawczych wyłoniły się zarówno założenia co do zakresu prac, jak i koncepcja merytorycznej zawartości bazy tekstów i w dalszej perspektywie zalażka korpusu, który jako propozycja miał być udostępniony do dalszych dyskusji.

U podstaw części bazowej korpusu legła myśl, by teksty, tak samo jak SPXVI, służyły nie tylko lingwistom, ale by stanowiły także ma-

14 Niestety nie zachowały się tzw. matryce będace wzorem dla kopii powielaczowych.

15 Niektóre błędy dostrzeżono już na etapie przygotowywania matryc powielaczowych i ręcznie naniesiono poprawki, które dodatkowo utrudniaja OCR. 
teriał źródłowy dla specjalistów $z$ innych dziedzin, np. historyków czy badaczy dawnego prawa i społeczeństwa, dlatego istotne było, by uzyskały formę elektroniczną o możliwie uniwersalnej postaci [Prinke 2000, 120 i nast.]. Przyjęto zatem kodowanie tekstów w języku XML w powszechnie stosowanym formalizmie TEI (Text Encoding Initiative) w wersji P5, ${ }^{16}$ który jest w stanie przechować metadane o niemal wszystkich cechach tekstu oryginalnego. Zalecenia TEI sa bardzo obszerne, należało zatem dokonać selekcji elementów i atrybutów, które będa miały zastosowanie w tekstach XVI-wiecznych. Dla wyboru języka XML istotne znaczenie miała też możliwość zakodowania informacji o niestandardowych znakach pojawiajacych się w dawnych tekstach, zatem do zestawu znaczników dodano listę encji znakowych, które miały reprezentować glify spoza standardowego zestawu znaków. Implikowało to z kolei konieczność wyboru odpowiedniego zestawu czcionek, który byłby w stanie wyświetlić zakodowane encje znakowe. W momencie opracowywania założeń najbardziej adekwatnym, a przy tym dostepnym na licencji open source, zestawem znaków był font Palemonas MUFI, opracowany w ramach projektu The Medieval Unicode Font Initiative. ${ }^{17}$

Jednym $z$ istotnych zadań projektu było zbudowanie narzędzia do wygodnego przepisywania tekstów XVI-wiecznych, które byłoby maksymalnie przyjazne dla użytkownika i jednocześnie pozwalało na zapis plików $\mathrm{w}$ formacie XML. Posłużył do tego edytor opracowany przez Bartosza Białego na potrzeby edycji haseł do elektronicznej wersji SPXVI. Edytor został wyposażony w dodatkowy moduł oparty na specjalnym schemacie (wybór z TEI), dzięki któremu możliwe stało się zakodowanie pełnej informacji lokalizacyjnej (strona, kolumna, wiersz), a dla tekstów biblijnych dodatkowo również podział na księgi, rozdziały i wersety. Nadto by oddać układ strony pierwowzoru, można było także wyróżnić takie elementy typograficzne tekstu jak marginesy, nagłówki, ozdobne inicjały, tabele, elementy graficzne, żywe paginy, kustosze. Możliwe również było oznaczenie zmiany kroju pisma, co jest istotne, nierzadko bowiem w XVI-wiecznych drukach pociagała ona za sobą zmianę oznaczania niektórych diakrytów, zwłaszcza pochyleń samogłosek.

By ułatwić późniejsze automatyczne przetwarzanie korpusu, zastosowano także wyróżnianie obcojęzycznych wstawek. Dla przyszłego zastosowania tekstów w pracach redakcyjnych nad SPXVI ważne było również zachowanie numeracji tzw. matryc, czyli poszczególnych fiszek składajacych się na egzemplarz archiwalny. Numery matryc zapisane w specjal-

16 https://tei-c.org/guidelines/P5/

17 https://skaldic.abdn.ac.uk/m.php?p=mufi lub alias http://www.mufi. info/ Niestety wybrany font został zoptymalizowany tylko dla środowiska Linux, a w programach działajacych pod kontrola systemu MS Windows pojawiaja się niedokładności w kształtach znaków, co będzie w przyszłości skutkowało koniecznością wyboru innego fontu lub opracowania specjalnego zestawu. 
nych tagach dodatkowo identyfikuja miejsce w tekście i pozwalaja łatwo odnieść się do szerszego kontekstu podczas analizowania danej fiszki, ponieważ nie zawsze na fiszkach oznaczano numery wierszy.

Przepisane teksty zostały poddane dwóm korektom. Pierwsza $z$ nich sprawdzała zgodność $z$ egzemplarzem archiwalnym, druga zaś polegała na kontroli względem oryginalnego tekstu w postaci fotokopii lub kopii cyfrowej. Sprawdzone pliki XML z pomoca arkuszy XSLT oraz XSL-FO poddane zostały przekształceniom, by uzyskać ich odpowiedniki w formacie HTML do publikacji w serwisie http://spxvi.edu.pl oraz PDF.

Każdy tekst $z$ bazy w nagłówku pliku w formie metadanych zawiera informacje o autorze, tytule tekstu i roku wydania. Poza tym w nagłówku umieszczono główne informacje dotyczące projektu oraz nazwiska osób pracujacych przy każdym tekście. Oczywiście istnieje możliwość, by w następnych etapach projektu umieścić w pliku szczegółowe metadane lub wyposażyć sam tekst w kolejne elementy opisujące go na różnych poziomach.

Obecnie zdeponowane w bazie teksty można przeszukiwać jedynie za pomoca wbudowanego w każda przeglacdarkę narzędzia (Ctrl+F lub F3) pod warunkiem, że znana jest przynajmniej przybliżona postać szukanego ciagu i to tylko w obrębie jednego tekstu (lub jego części w wypadku długich tekstów) załadowanego do przeglądarki. Jest to oczywiście rozwiązanie dalece niedoskonałe i potrzebne jest specjalne narzędzie pozwalające na dokładniejsze wyszukiwanie w ramach całej bazy, przy możliwości stosowania różnego rodzaju filtrów i kryteriów. Opracowanie takiego narzędzia zaplanowano w drugim etapie prac.

\subsection{Zalążek korpusu}

Część korpusową projektu stanowi zalążek korpusu, którego podstawowym założeniem była pełna integracja $z$ elektroniczna wersja SPXVI. W myśl tego założenia korpus miał się posługiwać stosowana w SPXVI nomenklatura i sposobem opisu gramatycznego, by ułatwić wzajemne odniesienia między słownikiem a korpusem. Podstawę utworzenia zalążka korpusu stanowiła baza tekstów XVI-wiecznych opracowana w pierwszym etapie projektu. Przyjęto również, że fragmenty tekstów użyte w zalążku zostaną wyposażone w warstwę transkrypcji, a każdy segment będzie skorelowany $z$ indeksem haseł słownika. Oprócz standardowego elementu base każdy segment otrzymał element base_id zawierajacy identyfikator hasła w indeksie. Za podstawę tagsetu korpusu posłużyła lista kategorii gramatycznych i form fleksyjnych opracowana przez A. Luto-Kamińska na podstawie Instrukcji redakcyjnej „Słownika” [Opaliński 2016]. Ponieważ tagset zalążka nie jest zgodny ze standardem tagsetu NKJP, elementy stosujace nietypowe wartości zostały nazwane inaczej jako xvi_ctag dla wartości kategorii gramatycznej oraz xvi_msd 
dla wartości formy fleksyjnej. Dzięki takiemu rozwiązaniu poszczególnym segmentom będzie można dodać standardowe elementy ctag i msd stosujące wartości ujednolicone dla korpusów diachronicznych. Każdy wreszcie segment korpusu zawiera atrybut, którego wartość jednoznacznie identyfikuje zarówno tekst, jak i miejsce segmentu w tekście.

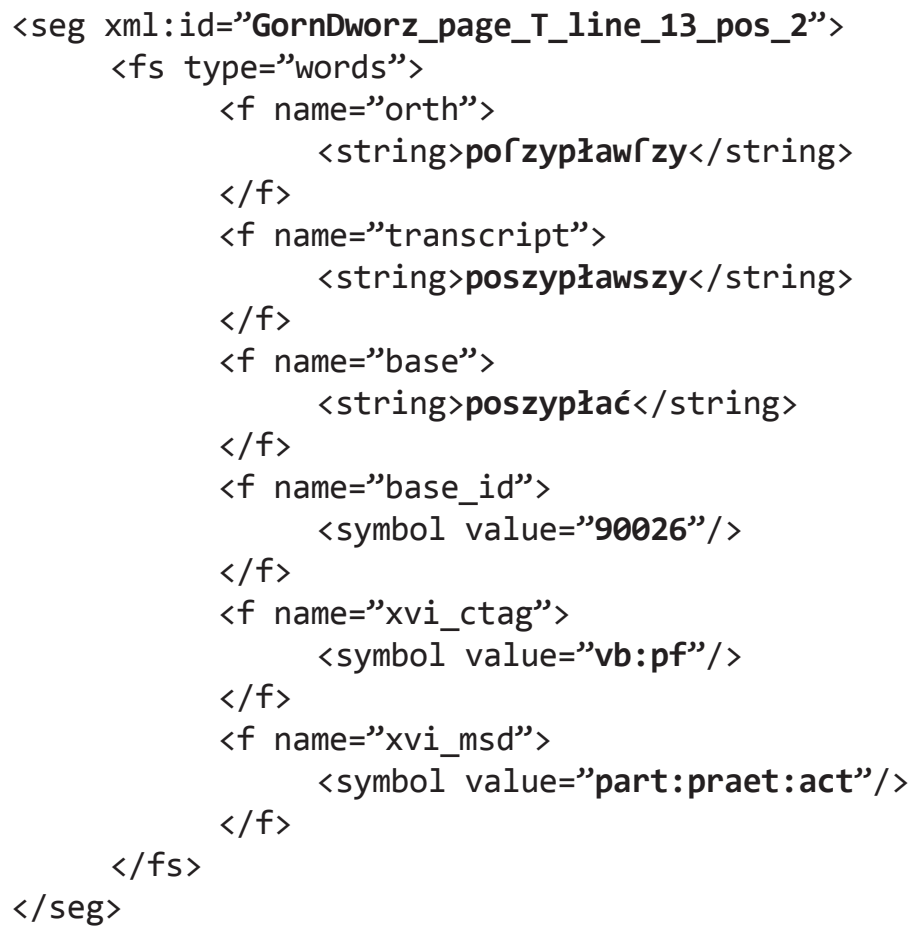

Tagowanie tekstów zalażka korpusu było ręcznie wykonywane przez anotatorów. Do tego procesu został ponownie wykorzystany edytor służący przepisywaniu tekstów $z$ dodatkowym prostym modułem pozwalającym na konwersję tekstu do formatu korpusu, a następnie na ręczną segmentację i tagowanie. Program jedynie podpowiadał możliwe wartości, ich ustalenie należało do anotatorów.

W wyniku ręcznego tagowania powstał zbiór 135 tysięcy segmentów, które zostały zdeponowane $\mathrm{w}$ bazie danych zarządzanej przez aplikację internetowa zintegrowana $z$ serwisem SPXVI. ${ }^{18}$ Prosta wyszukiwarka tymczasem pozwala na znalezienie żądanego ciagu na podstawie formy podstawowej (element base) lub transkrypcji (element transcript).

18 Wyszukiwarka korpusowa znajduje się pod adresem: https://spxvi.edu. pl/korpus/probka/szukaj 


\begin{tabular}{|c|c|c|c|}
\hline kontekst & źródlo & $\begin{array}{c}\text { lokalizacja } \\
\text { (strona/wiersz/pozycja) }\end{array}$ & $\begin{array}{l}\text { artykul } \\
\text { haslowy }\end{array}$ \\
\hline $\begin{array}{l}\text {... Bog tákową ráną náwiedził Bárwierz pofzyplawfyy [0 trochẹ wpuśćił knoth miẹdzy zálawthy } \\
\text {... }\end{array}$ & GómDworz & (1) $13 / 2$ & poszyplać \\
\hline
\end{tabular}

Wynik wyszukiwania oprócz znalezionego segmentu zawiera kontekst rozszerzony o pięć poprzedzających i pięć kolejnych segmentów. Postać tego kontekstu można przełączać między transliteracją a transkrypcją. $\mathrm{Na}$ podstawie atrybutu identyfikujacego segment $\mathrm{xml}$ :id formułowany jest link do odpowiedniego miejsca w tekście źródłowym, dzięki czemu można poszerzyć kontekst, wyświetlając cały tekst $z$ zaznaczoną lokalizacją segmentu, element base_id zaś pozwala na utworzenie linku do odpowiedniego hasła w elektronicznej wersji słownika.

\section{PLANY}

Obecnie trwaja prace przygotowujace do połączenia zarówno istniejących, jak i planowanych korpusów diachronicznych w jeden Narodowy Korpus Diachroniczny Polszczyzny [zob. Król i in. 2019]. W ramach Korpusu Polszczyzny XVI wieku zamierzone prace obejmują konwersję tagsetu do ujednoliconego systemu znakowania w przyszłym korpusie diachronicznym, rozszerzenie ręcznie znakowanego korpusu o kolejne 100 tys. segmentów, by wytworzyć bazę dla automatycznego tagera, a także wspomagana programowo transkrypcję tekstów transliterowanych. Do tych prac będa adaptowane narzędzia sprawdzone w projekcie KorBa, który obecnie wyznacza standardy dla planowanego Narodowego Korpusu Diachronicznego Polszczyzny.

Poza wspólnymi działaniami akcesorów NKDP w ramach samego Korpusu Polszczyzny XVI wieku będa podejmowane działania mające na celu jego dalszy rozwój. Zasadnicze prace będa polegały na włączeniu do bazy jak największej liczby tekstów spoza tzw. kanonu SPXVI. Obecnie jest to lista licząca ponad pół tysiąca tekstów różnej objętości i o różnej tematyce. Uwzględnienie tego zbioru pozwoli na znacznie większe zrównoważenie bazy przede wszystkim pod względem językowym, ale również jeśli chodzi o różnorodność reprezentowanych dziedzin. Ambicją twórców bazy jest zawarcie jak największej liczby tekstów polskich powstałych w XVI wieku. Wszystkie teksty znajdujace się w bazie maja być zaopatrzone w metadane możliwie najdokładniej opisujące zarówno językowe, jak i pozajęzykowe cechy tekstu, co pozwoli na wielopłaszczyznowe obserwacje. Planuje się również dodanie do transliterowanych tekstów warstwy transkrypcji, co będzie miało niebagatelne znaczenie dla późniejszego wykorzystania ich w korpusie, ale także znacznie ułatwi użytkownikom kontakt $z$ tekstem. Ponadto w zamierzeniach jest też wykorzystanie powstałego w ramach NKDP rozszerzonego i otagowanego 
korpusu do wspomagania prac redakcyjnych nad słownikiem. Pozwoli to $z$ jednej strony na przyspieszenie i do pewnego stopnia zautomatyzowanie procesu redakcji (zwłaszcza w części statystycznej), z drugiej zaś będzie okazją do weryfikacji automatycznej anotacji segmentów korpusu.

\section{Bibliografia}

D. Adamiec, 2015, Kryteria doboru tekstów do Elektronicznego korpusu tekstów polskich z XVII i XVIII w. (do 1772 r.), „Prace Filologiczne” t. 67, s. 11-20.

J. Bień, 2014, The IMPACT Project Polish Ground-Truth Texts as a DjVu Corpus, „Cognitive Studies | Études cognitives” nr 14, s. 75-84 (DOI: 10.11649/ cs.2014.008).

K. Górski i in. (red.), 1955, Zasady wydawania tekstów staropolskich. Projekt, Wrocław.

R. Górski, M. Łaziński, 2012, Reprezentatywność i zrównoważenie korpusu [w:] A. Przepiórkowski, M. Bańko, R.L. Górski, B. Lewandowska-Tomaszczyk (red.), Narodowy korpus języka polskiego, Warszawa, s. 25-36.

W. Gruszczyński, 2010, Jednostka opisu leksykograficznego $w$ słowniku historycznym na przykładzie „Słownika języka polskiego XVII $i$ 1. połowy XVIII wieku”, „Poradnik Językowy” z. 4, s. 26-40.

S. Hrabec, 1966, Historia „Słownika” [w:] Stownik polszczyzny XVI wieku, t. 1, Wrocław-Warszawa-Kraków, s. V-VII.

M. Król i in., 2019, Narodowy Korpus Diachroniczny Polszczyzny. Projekt, „Język Polski" nr 1, s. 92-101.

W. Kuraszkiewicz, 1966, Uwagi o statystyce w „Stowniku” [w:] Stownik polszczyzny XVI wieku, t. 1, Wrocław-Warszawa-Kraków, s. XIV-XXV.

M.R. Mayenowa, 1966, Charakterystyka „Słownika” [w:] Słownik polszczyzny XVI wieku, t. 1, Wrocław-Warszawa-Kraków, s. VIII-XIII.

K. Opaliński, 2007, Problemy kodowania korpusów historycznych (na przykładzie tekstów XVI-wiecznych) [w:] J. Kamper-Warejko, I. Kaproń-Charzyńska (red.), Z zagadnień leksykologii i leksykografii języków słowiańskich, Toruń, s. $107-114$.

K. Opaliński, 2016, Korpus polszczyzny XVI wieku. Tagset (na podstawie opracowania A. Luto-Kamińskiej) - do użytku wewnętrznego, Torun.

T. Piotrowski, 2001, Zrozumieć leksykografie, Warszawa.

T. Piotrowski, 1993, $Z$ zagadnien leksykografii, Wrocław.

R. Prinke, 2000, Fontes ex machina. Komputerowa analiza źródeł historycznych, Poznań.

A. Przepiórkowski, M. Bańko, R.L. Górski, B. Lewandowska-Tomaszczyk (red.), 2012, Narodowy korpus języka polskiego, Warszawa.

Z. Saloni, 1996, Perspektywy polskiej leksykografii jednojęzycznej, „Poradnik Językowy" z. 7, s. 1-18.

Słownik polszczyzny XVI wieku. Zeszyt próbny, 1956, Wrocław.

Ł. Szałkiewicz, 2013, Lematyzacja $w$ ręcznej anotacji milionowego podkorpusu Narodowego Korpusu Języka Polskiego - ciekawe przypadki, „Polonica” r. 33, s. $133-156$. 
[K. Wilczewska], 1976, Instrukcja redakcyjna „Słownika polszczyzny XVI wieku”, Torun - druk IBL PAN do użytku wewnętrznego, udostępniony za zgodą autorki i IBL PAN pod adresem: http://spxvi.edu.pl/instrukcja

K. Wilczewska, 1966, Zasady redakcyjne „Słownika” [w:] Słownik polszczyzny XVI wieku, t. 1, Wrocław-Warszawa-Kraków, s. XXVI-XLII.

Zapiski i roty polskie XV-XVI wieku z ksiag sadowych ziemi warszawskiej, 1950, wyd. W. Kuraszkiewicz i A. Wolff, Kraków.

P. Żmigrodzki, 2005, Słownik jako korpus tekstów - korpus tekstów jako słownik. Perspektywy polskiej leksykografii naukowej, „Poradnik Językowy” z. 6, s. 3-14.

P. Żmigrodzki, 2009, Wprowadzenie do leksykografii polskiej, Katowice.

\section{Corpus of the $16^{\text {th }}$-century Polish language}

\section{Summary}

The original purpose of creating the corpus of the $16^{\text {th }}$ Polish language was to preserve the material basis of Słownik polszczyzny XVI wieku (Dictionary of the $16^{\text {th }}$-Century Polish Language) (SPXVI) comprising 272 texts transliterated in accordance with standardised principles, which is of great value. The project described here consists in creating an online base of the resources and using a part of it as a germ of a language corpus with texts designated with morphosyntactic markers.

The works adopted XML encoding in the TEI (Text Encoding Initiative) formalism, version P5, adjusted to a $16^{\text {th }}$-century text. Typographical elements as well as grammatical categories and forms of words were designated in the texts. The germ of the corpus of the $16^{\text {th }}$-century Polish language comprises 135 thousand segments and it will be expanded by another 100 thousand in the future to provide material for an automated form designation tool. Ultimately, integration with the Diachronic Corpus of Polish is planned.

Keywords: lexicography - history of Polish - diachronic corpus of Polish

Trans. Monika Czarnecka 